\title{
Figurated Corbels on Romanesque Churches: The Interface of Diverse Social Patterns Represented on Marginal Spaces
}

\section{Barry Magrill}

Volume 34, numéro 2, 2009

URI : https://id.erudit.org/iderudit/1069488ar

DOI : https://doi.org/10.7202/1069488ar

Aller au sommaire du numéro

\section{Éditeur(s)}

UAAC-AAUC (University Art Association of Canada | Association d'art des universités du Canada)

\section{ISSN}

0315-9906 (imprimé)

1918-4778 (numérique)

Découvrir la revue

Citer cet article

Magrill, B. (2009). Figurated Corbels on Romanesque Churches: The Interface of Diverse Social Patterns Represented on Marginal Spaces. RACAR : Revue d'art canadienne / Canadian Art Review, 34(2), 43-54.

https://doi.org/10.7202/1069488ar

\section{Résumé de l'article}

Cet article relie les figures sculptées ornant l'architecture des petites églises bâties au douzième siècle dans des coins reculés des îles britanniques aux modalités du regard qui ont permis la convergence de diverses classes sociales en un seul lieu. Bien que beaucoup de ces sculptures soient de nature sexuelle et que leur signification semble se rattacher aux campagnes que l'Église du Moyen-Âge menait contre l'immoralité, un examen plus approfondi de l'expression des codes sociaux et des conditions économiques liés à leur programme iconique offre de fructueux résultats. L'auteur constate qu'un large éventail d'observations, émises au départ d'expériences de vie hétérogènes, a donné lieu à des interprétations très diverses de la même imagerie. Installées sur les encorbellements qui dépassent des corniches des toits et contribuent au soutènement horizontal du bâtiment, ces figures sculptées sont le fruit d'une production qui impliquait à la fois le clergé, le mécène du projet et toute une collaboration artistique. Sans toutefois donner lieu à l'élaboration d'un programme iconographique homogène, la combinaison de leurs efforts apparaît plutôt emblématique d'un registre de croyances religieuses, morales et sociales habitant des individus aux points de vue extrêmement différents.
Tous droits réservés @ UAAC-AAUC (University Art Association of Canada | Association d'art des universités du Canada), 2009
Ce document est protégé par la loi sur le droit d'auteur. L'utilisation des services d’Érudit (y compris la reproduction) est assujettie à sa politique d'utilisation que vous pouvez consulter en ligne.

https://apropos.erudit.org/fr/usagers/politique-dutilisation/ 


\title{
Figurated Corbels on Romanesque Churches: The Interface of Diverse Social Patterns Represented on Marginal Spaces
}

\author{
Barry Magrill, University of Victoria
}

\begin{abstract}
Résumé
Cet article relie les figures sculptées ornant l'architecture des petites églises bâties au douzième siècle dans des coins reculés des îles britanniques aux modalités du regard qui ont permis la convergence de diverses classes sociales en un seul lieu. Bien que beaucoup de ces sculptures soient de nature sexuelle et que leur signification semble se rattacher aux campagnes que l'Église du Moyen-Âge menait contre l'immoralité, un examen plus approfondi de l'expression des codes sociaux et des conditions économiques liés à leur programme iconique offre de fructueux résultats. L'auteur constate qu'un large éventail d'observations, émises au départ d'expériences de vie hétérogènes, a donné lieu à des interprétations très diverses de la même imagerie. Installées sur les encorbellements qui dépassent des corniches des toits et contribuent au soutènement horizontal du bâtiment, ces figures sculptées sont le fruit d'une production qui impliquait à la fois le clergé, le mécène du projet et toute une collaboration artistique. Sans toutefois donner lieu à l'élaboration d'un programme iconographique homogène, la combinaison de leurs efforts apparaît plutôt emblématique d'un registre de croyances religieuses, morales et sociales habitant des individus aux points de vue extrêmement différents.
\end{abstract}

$T_{h}$ twelfth-century churches in England, no less than elsewhere in Europe, reflected the diverse social and economic patterns of its viewers. These patterns included the intersecting practices and behaviours of nobles, clergy, artists, and serfs (peasants who laboured in the lord's domain). The social and economic hierarchy among these people cultivated diverse religious, moral, and social beliefs, which are represented on inaccessible but highly decorative parts of churches. Among the so-called marginal spaces associated with the church fabric, particularly on corbels found under the eaves of the roof and in support of a horizontal string course, carving unexpectedly reflects social and economic views of the period. This paper will consider specific examples of such carving found on corbels at the twelfthcentury churches of St. Nicholas, Barfreston, Kent (ca. 1185) (fig. 1), St. Nicholas, Studland, Dorset (ca. 1140), and SS Mary and David, Kilpeck, Herefordshire (1134).

Brief descriptions of the three churches shall indicate how wealth was distributed around the body of the building. The two-cell church of St. Nicholas at Barfreston is lavishly covered with a variety of carved sculpture, featured on three doorways (an elaborate south entrance, a priests' door in the south chancel, and a north doorway), a wheel window with voussoir stones carved on the interior and exterior, and a corbel cable running around the south, east, and north sides. The upper section of the church employs Caen limestone supported by a cladding of local knapped flint. Everywhere the delicacy of the carving, though worn, indicates craftsmen familiar with metalwork, especially notable in the beaded motifs running along the horizontal string courses. The simple two-cell layout and its decoration remain entirely of the late twelfth century. The interior embellishments include acanthus capitals with twisted fluting of the shafts in the chancel arch in addition to rich dragons, beasts, heads, and foliage on the wheel window's voussoirs.

St. Nicholas in Studland has a three-cell plan consisting of a square chancel, central tower, and aislcless nave. Later ad- ditions include the south porch and the southwest buttress of the tower. Rich ashlar masonry (neatly finished stonework) used selectively on the north and south walls of the chancel, as well as on the tower buttresses, contrasts with the primarily rubblebuilt construction of the walls in the nave and eastern end. The entire fabric sits upon a plinth that is visible on all sides. Two Romanesque windows survive in the north wall of the nave, while the richer triple-lancet window in the east wall represents a later modification. 'I he alterations to window arrangement and articulation were mainly aesthetic choices, rather than functional necessities, which trace how money was apportioned in remodelling. Elaborate carving was reserved for the corbel table running along the north and south walls. The interior boasts a quadripartite rib vault in the chancel, in contrast to a wood-roofed nave, again showing greater expenditure on areas of most liturgical importance.

Kilpeck church has a three-cell division, similar to Studland, but Kilpeck has a semi-circular apse in the east end. The nave and chancel are built of rubble masonry except for the use of an ashlar finish on the pilaster buttresses and round-headed window mouldings. The east-end apse has roughly squared smaller stones, which illustrates that more money was expended on areas of the church building that were associated with higher liturgical function. The ornamentation of windows in the apse similarly displays greater attention to detail with the inclusion of roll mouldings. Further distinctions are articulated through the stone vaulting of the apse, distinguishing it from the wood roofing of the nave and chancel. A particularly rich program of carving is found on the south doorway, including a marvellous assortment of imaginary beasts carved on the voussoirs, the west window, and the corbel table running the full circumference of the church. ${ }^{1}$ Kilpeck, Barfreston, and Studland illustrate that expense was not only distributed on the eastern end of the buildings but also that the corbel tables, spread along the entire length of the façades, represented a conspicuously large portion of the cost of the sculptural programs. 


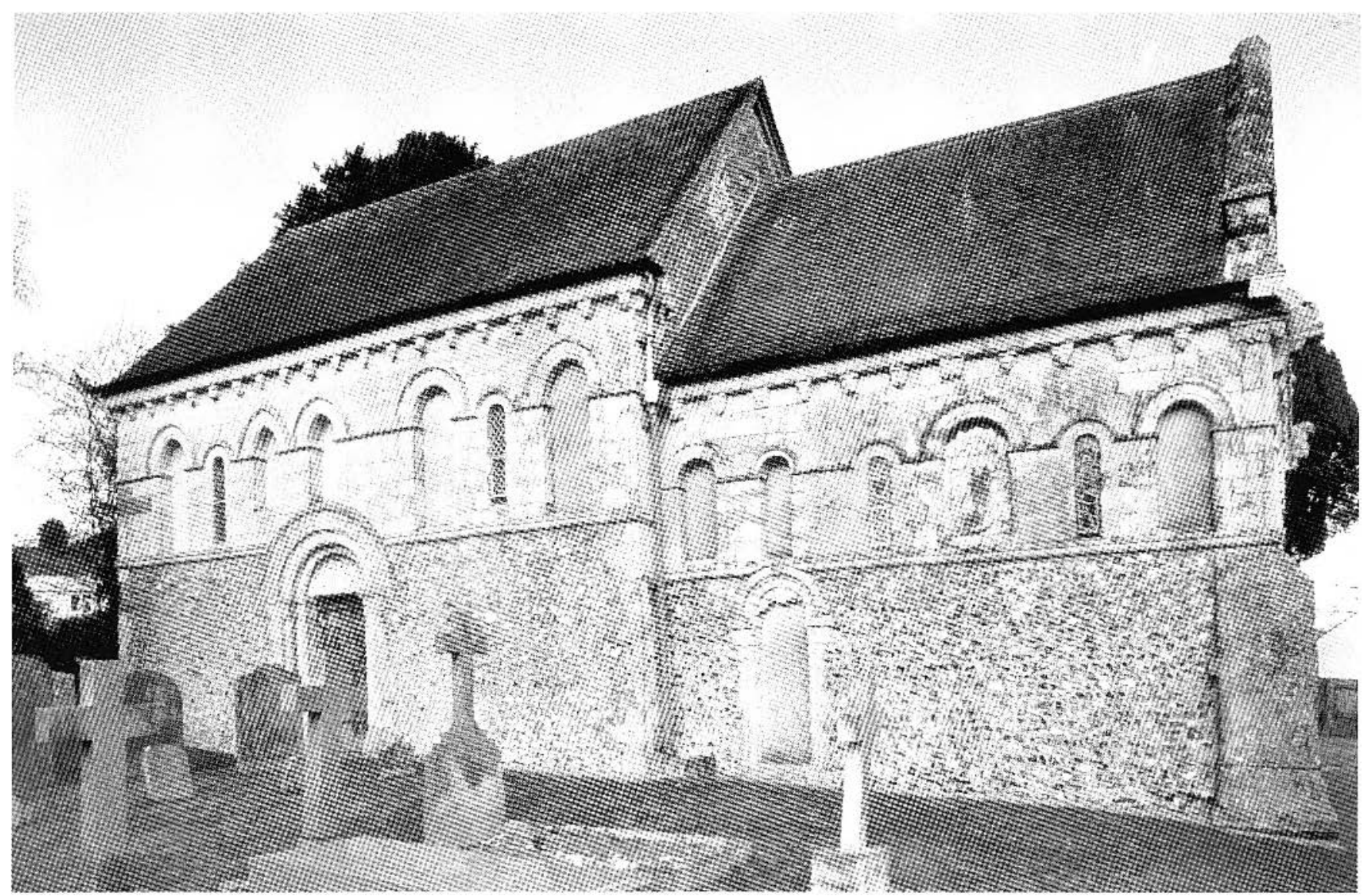

Figure I. St. Nicholas, Barfreston. Kent, from the southeast (ca. 1185) (Photo: Malcolm Thurlby).

The scope of the corbel imagery encountcred at these three Romanesque churches is wide. 'This paper focuses on a selection of human and animal figures and heads, leaving the carvings of foliage and geometric shapes for future discussion. Carved corbcls are specialized architectural details, and deserve more attention and study. The architect and author Joseph Gwilt offers a precise visual description of corbels in his encyclopedia of 1842 , published at the beginning of the period of the empirical study of medieval architccture. ${ }^{2}$ He lists corbels as "a range of stones projecting from a wall for the purpose of supporting a parapet or the superior projecting part of wall. Their fronts are variously moulded or carved." 3 Clearly, Gwilt was thinking of largescale buildings because he neglected to mention that corbels also appear beneath the eaves of the roofs of small churches and chapels. Gwilt's description, reflecting the nineteenth-century focus on monumentality, is nonetheless valuable for illustrating the marginal position of corbels because of their location at the extreme limits of the architectural fabric of churches. It is not surprising, then, to see corbel carving neglected in the literature on medieval architecture. However, the enormous number of carved corbels attached to English cathedrals, and especially to small churches and chapels, contradicts the idca of their insignificance. There were intimate rclationships between the imagery carved on corbels and the viewers, a divcrse network of groups and individuals interconnected through the production of food, goods, labour, and even art. The privileged existence of the lord of the medieval manor was constituted by a complex social and economic relationship with the ordinary folk working and living on his land. Consecuently, it is worth studying how the diverse social patterns were represented in the spaces of churchcs where corbels were carved.

\section{Carved Corbels as Important Contextual Markers}

Past scholarship around corbels, and architectural sculpturc in general, has largely focused on the issue of patronage and iconography, disadvantaging serious interest in alternate associations with socio-economic and spatial contexts. The amount and quality of carving on the fronts of corbels certainly offer clues to determining the wealth of a particular patron, but 
the spaces in which the carving occurs and the sort of imagery found there surcly offer clues to additional interpretations. However, there are several barriers to alternative interpretations. One is the preference among researchers to look for neat, logical visual narratives among the corbel carvings in English churches. Thus far, this approach has run into blind alleys, at worst, or has shown that sculpture found in marginal spaces was insignificant, at best. ${ }^{4}$ Individual motifs often seemed to coincide with fragments of whole narratives carved clsewhere in Europe, particularly in France. This led to the belief that English patrons and artists copied motifs from orher churches without understanding their inherent, but complex, series of meanings. This supposition clearly privileged French medieval sculptural production, placed emphasis on religious interpretation, and disallowed other social and cultural importance of corbels carved in Britain. An alternate position is that the carvers and patrons of English corbels chose imagery and placement with specific intent, which becomes clear through an analysis of the spatial and social contexts of the corbels found in Britain.

Before addressing the operation of these contexts, an assessment of the literature on corbels and marginal sculpture will illustrate the importance of using new methodologies for the study of corbels. The initial difficulty in assessing the existence of religious narratives embedded in the corbel stones at small, twelfth-century English churches points to three interrelated assumptions about the carvings that have become almost universally accepted at face value. First, the lack of an apparent sequential narrative developing from one stone carving to its neighbour was assumed to mean that English carvers were uninventive and simply copied Continental models. ${ }^{5}$ But even if one accepts this assumption, it does not negate the possibility of a relationship between sculpture and viewer. The widely held belief that patrons of medieval English churches were culturally undeveloped, preferring the aesthetics of popular morifs, such as hybrid animals, without having a concrete knowledge of the accompanying religious doctrine and moral codes, does not supersede the likelihood that viewers of various social strata saw what they wanted to see in the imagery. 6

Second, the marginal location of corbels at the juncture of the wall and roof and in places usually difficult to see was assumed to mean that carvers exerted artistic autonomy over the production of the motifs. Nurith Kenaan-Kedar's Marginal Sculpture in Medieval France (1995) raises similar points by arguing that medieval artists and their patrons were separate classes of people, the former group resisting the economic and social dominance of the latter. Yet, it has still to be proven that a marginal status of sculpture occurring at the extremities of the church fabric has been bestowed by any other than the modern observer. It may be that corbel carving had appreciative audiences whose visual acumen was savvy enough to read these differently than, for instance, figurative capitals.

Third, the supposed autonomy of carvers producing corbel sculpture was assumed to have increased the opportunity for the expression of personal and group sexuality, not so much as an endorsement of the Church's moralizing codes but in resistance to those codes. Anthony Weir and James Jerman, in Images of Lust: Sexual Carvings on Medieval Churches (1986), contextualize the production of what they considered to be sexually charged imagery in the behaviour patterns of producers and audiences. Weir and Jerman attempt to prove that medieval carvings of a sexual nature were actually sanctioned by the Church in France and the British Isles in a campaign against immorality, and therefore were neither pornographic nor sacrilegious. For thcm, the sexual motifs in France, though more explicit, indicated warnings against scxual misconduct on par with the warnings represented by Sheila-na-gigs, explicit female figurcs exposing the vulva, found in the British Islcs. ${ }^{7}$ Still, their approach divides the social spectrum into prototypical hierarchies, a significant misstep in trying to understand the complex social terrain of the twelfth century. In this paper, I regard the corbel table as a space wherc elite and ordinary viewers interacted; thus, I describe how separate social classes saw different meanings in the same carvings, based upon vastly different lived experiences. Historian Aron Gurevich, in Medieval Popular Culture, points out this interconnectivity via his observations of medieval literature. ${ }^{8}$ Gurevich investigates popular culture from the viewpoint that a so-called elite layer of society lowered opinions about certain cultural treasures in order to benefit from the hierarchies so constituted. Critics argue that he makes arbitrary distinctions between the social layers, which problematizes understanding the thought patterns of ordinary people who barely left a trace in the records kept by a literate class. My attention to the more permanent art of stone carving and its exhibition in the public sphere may access richer ways in which viewers developed, institutionalized, and claimed a wide variety of associated meanings from groups of sculpture.

Architectural sculpture robustly exemplifies the spatial relationships of margin and centre linked to social dealings. In Image on the Edge, Michacl Camille adopts the position that images in the margins of medieval manuscripts were popular among audiences because they spoke in a common language even the illiterate would understand. ${ }^{9}$ Though Camille's framework tends to crcate problematic distinctions between folk and institutional cultures, he makes a strong case in favour of different medieval classes and mentalities sharing the same visual space. Essentially, he takes the existence of low class or popular marginalia on institutionally produced religious manuscripts as indicating that each culture was represented in the space of the other. 
The approaches noted above illustrate that scholarship has offered a variety of interpretations of marginalia in manuscripts that may be applied to medieval sculpture occurring on the more remote parts of buildings. In the case of corbels carved onto smaller churches in twelfth-century England, we search in vain for iconographic meaning that fits into a neatly arranged visual narrative. To persist in this approach disadvantages the fundamental socio-spatial problems. How were the diverse social lives of the viewers of medieval corbels represented in the spaces where the corbels occurred? What parts of privileged and ordinary lifescyles were reflected in the carvings and in the marginal spaces where corbels were installed? What follows is a case study of the interconnection of sculpture and spatial practice at Romanesque churches in Barfreston, Kilpeck, and Studland, built by different patrons, where similar motifs were placed in the same general configurations-beneath the eaves of the roofs and under horizontal string courses.

Corbel carving has been the neglected cousin of doorway carving, including tympana and voussoir stones, which typically display more unified iconography. ${ }^{10}$ In fact, the logical visual narratives found on doorway carving have often been contrasted to the so-called irrational arrangement of corbel tables, with their medley of imagery. However, the south doorway at St. Nicholas in Barfreston is precisely an example of a carving made famous by its lack of a unified visual story." Its tympanum contains a Christ in Majesty, a king and queen, a possible ser of patrons, and an assortment of angels. The double register of voussoir stones surrounding the arched doorway depicts numerous unconnected themes that include some signs of the zodiac, literary sources from the Holy Scriptures, the lives of the saints, the encyclopedic books of beasts (also known as bestiaries), and earlier versions of the Physiologus, which also contained a moralizing component. ${ }^{12}$ For F.H. Worsfold, author of the 1949 guide to the carving at St. Nicholas, Barfreston, none of the carvings tie together in a kind of meaningful unity he wished to find there. Worsfold was not alone in this supposition. Years earlier, in 1933, Reverend A.H. Collins published an article noting that the carver of Barfreston had "capriciously chosen a few subjects, and then passed on to some other fancy." 13 Thenceforth, the corbel carving at Barfreston was assumed to amount to very little beyond the same sort of decoration lacking coherent meaning that existed on the south doorway. ${ }^{14} \mathrm{~A}$ case in point is the upside-down depiction of two wrestlers, assumed to have been improperly installed by an inexperienced mason. However, my examination of the voussoir stones on the south doorway suggests that no other combination of stones would have resulted in all the figures in upright positions. Thus, the inverted wrestlers must have been intentional, though the precise meaning of this image remains elusive.
Categorizations and terminologies are important considerations when dealing with carved corbels, which have had a series of loaded terms attached to them since at least the nineteenth century. J. Romilly Allen's Norman Sculpture and the Medieval Bestiaries (1887), for example, initiated a canon of terminology for medieval imagery. Allen was one of the first English researchers to cobble together an index of motifs in sculpture attached to architecture, which he compiled from descriptions found in medieval bestiaries. 15 His inventory and categorization of carved morifs involve ambiguous and overloaded designations, relying heavily upon terms such as grotesque, and analyses of iconography rather than social context. For general purposes of terminology, I propose alternative designations that include the terms geometrical, foral, human, animal, and hybrid. Rather than reapply canonical approaches, I prefer to think broadly across a wide variety of imagery in order to probe some common social and economic threads.

The variety of the imagery occurring on the carved corbels at the churches in Studland, Kilpeck, and Barfreston was characteristic of overall corbel sculpture found throughout twelfth-century Britain. For instance, an assortment of human heads, caricatures, hybrid creatures, animals, floral, and complex geometric shapes are found among the nearly seventy separate carved corbels lining the north, south, and east ends of the small, two-cell church at Barfreston. A portrait of a monk with a tonsured haircur located not far on the corbel table from creatures displaying human/animal characteristics is a remarkable spatial relationship, but not one unusual for corbels.

\section{The Ambition and Status of Patrons}

Carved corbels became popular among ambitious patrons of the twelfth century. Carvings of plant and human figures made on corbels were used initially in grand building projects, where patrons could well afford to pay for additional masons, including those at Chichester Cathedral (Sussex, 1080s or 1090s), Ely Cathedral (Cambridgeshire, before 1106), Winchester Cathedral (Hampshire, after 1107), and Romsey Abbey (Hampshire, after 1120). Following this introduction of carved corbels into the architectural grammar of English architecture at the end of the eleventh century, the morifs became a staple part of the repertoire for the adornment of grcatcr and lesser ecclesiastical buildings.

The expenditure of private wealth on church buildings located in the public domain became a form of conspicuous consumption. The added expense of hiring masons to carve corbels likely became an expectation among socially ambitious patrons seeking to grow even the most modest private fortunes. Those moving up the social and economic register appear to have ex- 
pected architecture and architectural sculpture to assist in these aims, yet at the same time their patronage was keenly tied to personal piety. One not only gave money toward the enrichment of religion for the sake of satisfying the Almighty, but one also often did so in as public a manner as possible in order to enjoy social privilcge on earth.

As a result, the cconomy of building churches was closely associated with the expression and social construction of power. For instance, Kilpeck's patronage is attributed to Hugh, lord of Kilpeck Castle, whosc political and economic position was considerable. Because William the Conqueror's success in England, after the decisive Battle of Hastings in 1066, depended upon giving his close associates land and privilege in exchange for the creation of trade and the development of the architectural infrastructure, numerous castles and churches were constructed. Construction of new and renovated churches was so prolific after 1066 that William of Malmesbury wrote about ccclcsiastical buildings springing up in every town and village. 16 In the geographical region of Kilpcck this gave rise to the creation of a regional school of sculpturc referred to in the literature as the Herefordshire School.1?

The church of St. Nicholas at Studland has no documented builder, although the Domesday Book-an inventory of the property held in England after William of Normandy defeated the Saxon King Harold in 1066-shows that the land was held by Robert, Count of Mortain, half-brother of King William and younger brother of Bishop Odo of Bayeux. ${ }^{18}$ Studland's patron appeared concerned with the pursuit of social status, given how the small church's corbel carving emulated that found at larger church buildings at Winchester, Romsey, Reading, Leominster, Portchester, and Kingsclere. The latter churches resulted from the direct patronage of the highest order, that of King Henry I. One particular corbel motif used at Studland that was derived from the churches paid for by Henry consists of a circle enclosing a curved diamond shape and incised cross. 19 The same motif was used at the cathedral at Old Sarum, built by its bishop, Roger, who also moved in elevated social circles. ${ }^{20}$ Such a motif appeared to operate as a visual code known to all viewers across the social spectrum, and especially those of high birth.

The patronage of St. Nicholas at Barfreston is more complicated. The Domesday Book shows that the village of Barfreston was part of the vast estates of Odo, Bishop of Bayeux, but the inventory does not list a church. ${ }^{21}$ After Bishop Odo's disgrace in 1081 due to charges of treason, the village was made a dependant of Dover Castle.22 It is believed that one of the sub-constables of Dover, Hugo de Port, held the manor at Barfreston. His grandson, Adam de Port, built the small, twocell church as part of a marriage alliance with another wealthy family, the d'Orval family of Normandy. 23 The construction of the church on the occasion of a marriage that merged these two wealthy families heralded the Norman bloodline of the de Port family. Visually, this church ranked as a gem among small ecclesiastical buildings; the upper portion of the structure was clad in Caen limestone and each of its three doorways was adorned with sculpture. How the de Port family was able to afford the grand sculptural program remains unclear, but the abundance of ornament does indicate its use as an instrument to incrcase the patron's social and economic status, within the broader umbrella of pious worship. The church of Barfreston, like those of Studland and Kilpeck, displays a richness of sculpture inversely proportional to the size of the building. In other words, the detailed quality of the carving, rather than monumental architecture of the building itself, was meant to impress the viewer. The de Port family, in particular, chose to express status through the robustness of the sculptural program on its small church. For Hugo de Port, like most wealthy patrons seeking to augment power and prestige, architectural sculpture was onc of many tools available to him. However, the lord of the manor did not have complete autonomy in all decisions of an artistic and religious nature, and he would have worked in concert with the clergy and the artisans. This would include achieving clerical approval for imagcry that existed in a mason's repertoire. Patrons such as the de Port family participated in an economic and religious system that considered the expenditure of capital on churches to be proportional to an entitlement to enter heaven. The clergy were carcful to avoid the appearance of selling salvation, although the construction of churches was a functional necessity that had to be encouraged to maintain the business of religion and the social order. Nonetheless, a mixture of serious and humorous depictions on the corbel table appears to suggest a matrix of social influences at work.

The marginal spaces where corbels occupied the church fabric appear to have described the interface between economic and social practice, just as the choice of corbel motifs was an example of collective agreement between patron, clergy, and mason. Sculpture on churches was ordered and paid for by the piece, balancing the cultural capital wielded by artists with the symbolic capital and economic capital dispensed through clergy and patron, respectivcly. It is likely that the clergy chose disturbing images of beasts and hybrid creatures in order to maintain social control by instilling fear in ordinary folk. Meanwhile, the same motifs could have had the dual effect of eliciting fright and laughter. That is, people from all levels of society continued to commit sin, particularly sexual sin, despite being shown the most terrifying and visceral warnings. As we will see, there was something about the carvings on the corbel tables that viewers across the social and economic spectrum identified with on a personal level. The so-called marginal spaces on the church 


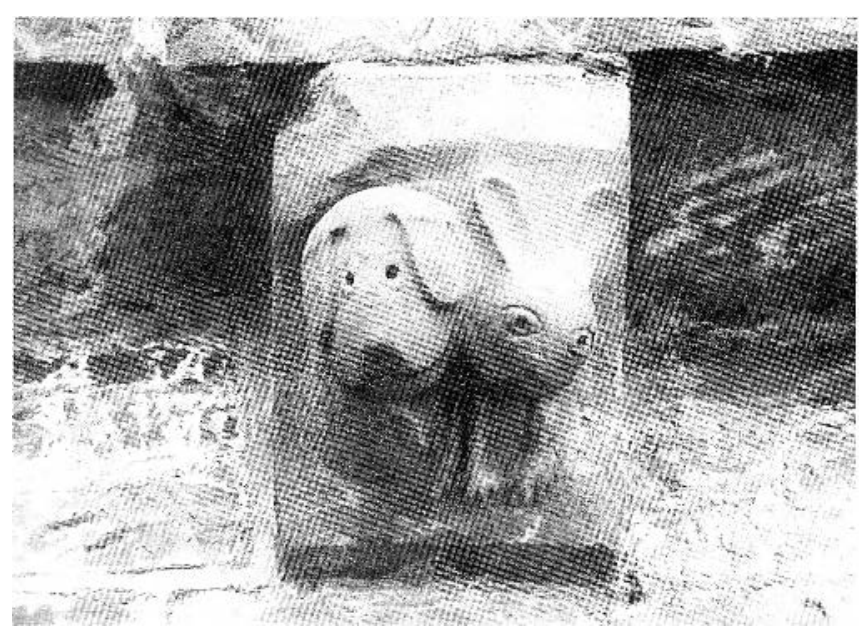

Figure 2. Corbel no. 33 (rabbit and dog). St. Mary and St. David Church. Kilpeck, Oxírdshire (Photo: Malcolm Thurlby)

where corbels occurred were not the exclusive domain of the nobility. Corbels located on the exterior of a church or a privatc chapel intended for the use of the lord's family were also in the public domain. Ordinary folk were free to interpret the imagery any way they saw fit, even though the clergy would likely have included the same imagery in moralizing sermons. When the ordinary folk had exited the church after the conclusion of a sermon, they encountered the carvings on the corbel table in secular space. Some of the carvings would have reinforced the moralizing messages they had just heard, while other carvings disrupted those same messages.

\section{Motifs in the Margins}

Patrons were surely aware that the space where corbcls were located did not have the same level of religious significance as that occupied by the high altar. Even within collective agreements berween patron, clergy, and mason there was likely some looser play with the religious themes found on the corbel table. Nikolaus Pevsner observes the corbels at Kilpeck to have "an irresistible comic-strip character." 24 For instance, the imagery of a dog and rabbit exhibit a cartoon-like quality (fig. 2). It is possible that these motifs elicited humorous responses from across the economic and social spectrum.

Still, some corbel motifs were likely envisioned to serve an educational and liturgical function. For instance, at Kilpeck there are two Agnus Dei (Lamb of (rod) motifs that appear to have educational motives. One of these motifs is set above the south doorway, the main access to the church's interior, and the other is located on the axis of the apse. Both appear deliberately located at junction points, the first where the visitor makes the

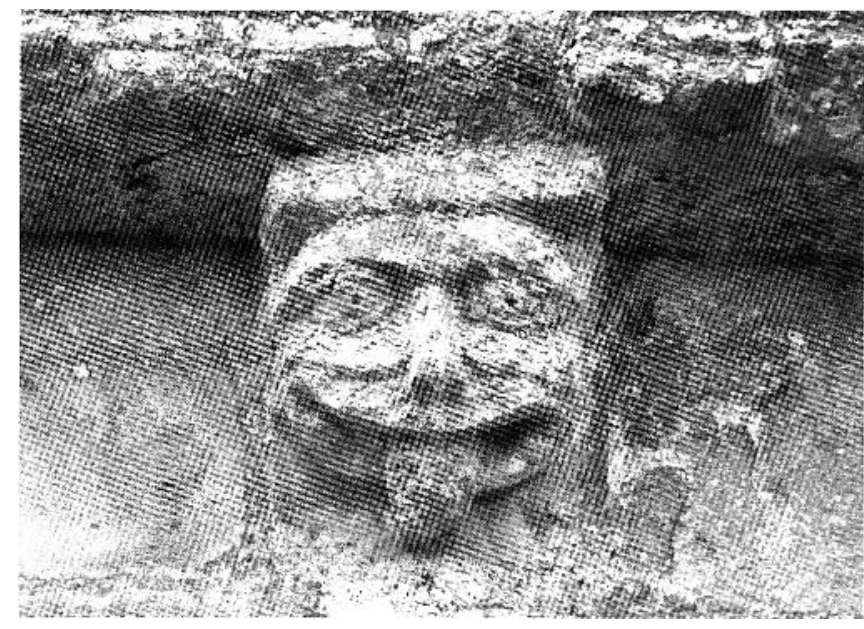

Figure 3. Corbel no. 2 (deformed head, tongue-protruder), east end under a string course, St. Nicholas, Barfreston, Kent (Photo: Barry Magrill)

transition from the secular space of the outside world, and the second on the interior where the visitor — now seeking spiritual purification-approaches the liturgically important altar located at the east end of the church. It appears that the locations of the Kilpeck Agnus Dei werc not accidental. In another instance, at St. Mary's Church, Kirkburn (Yorkshire), there is a corbel carved with an Agnus Dei that was moved to a position west of the south porch but was set originally above the south door, as at Kilpeck. There are also Agnus Dei depicted in the voussoir stones of the south doorways at the Romanesque churches in Alne, Birkin, and Brayton (all in Yorkshire). At Thwing Church (Yorkshire) the same imagery appears in the tympanum of the south doorway.

Bccause an Agnus Dei at Kilpeck was located near a significant spiritual portal and another on the exterior of the church, it may indicate that subsidiary spaces were sometimes highly charged with religious themes. However, when thinking about the occurrences of the Agnus Dei carved onto corbels, one also has to reconcile why the highly charged religious motif was carved onto an architecturally false member. By "false" I mean a component that appears to carry or redistribute the weight from a roof or vault. In fact, the corbels serve only as aesthetic support devices.

Medieval audiences understood that religious doctrine permeated all aspects of medieval life and therefore could be depicted on any part of the church fabric. At the same time, illiterate, superstitious, and less educated viewers associated all kinds of otherworldly beings with religion and spirituality. Standing in contradistinction to the positive moral expression of the Agnus Dei were corbel motifs that depicted terrifying creatures. 


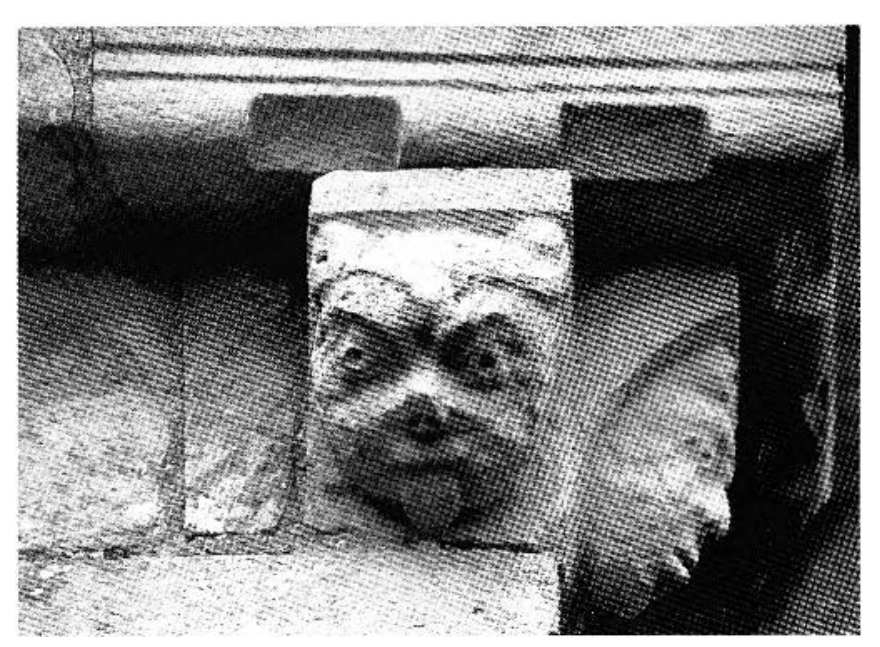

Figure 4. Corbel no. 20 of the south nave (tongue-protruder). St. Nicholas, Barfreston. Kent (Photo: Barry Magrill).

\section{Beautiful Deformity}

The notion that the corbcl table was not only a marginal space but also one that connccted elite and ordinary folk leads further to the idea that viewers' responses varied according to their social and official rank. For instance, when St. Bernard of Clairvaux (1090-1153) wrotc to his friend William, abbot of St. Thierry, to complain about the indecency of cloister sculpture, he chose the phrase "What profit is there in those ridiculous monsters, in that marvelous and deformed comeliness, that comely deformity?" Bernard continued:

What are the filthy apcs doing there? The fierce lions? The monstrous centaurs? 'The creatures, part man and part bcast? The striped tigcrs? 'The fighting soldiers? The hunters blowing horns?... In short, everywhere so plentiful and astonishing a variery of contradictory forms is seen that onc would rather read in the marblc than in the books, and spend the wholc day wondering at every single one of them than in meditating in the law of God. Good God! If one is nor ashamed of the absurdity, why is one not at least troubled at the cxpensc?25

The fact that Bernard gave an "official" response to marginal motifs illustrates that these objects did not escape the Church's attention. Most interestingly, he crafted an appeal to decency based not only upon moral judgment but also upon economy. Should not people be troubled, he reasoned, by the expense associated with the production of hybrid creatures, "part man and part beast"? How far St. Bernard's admonitions extended into the realm outside the cloister remains unclear. Yet, pcople were captivated by the sort of deformed and contorted heads that appeared, for instance, beneath a string course located on the

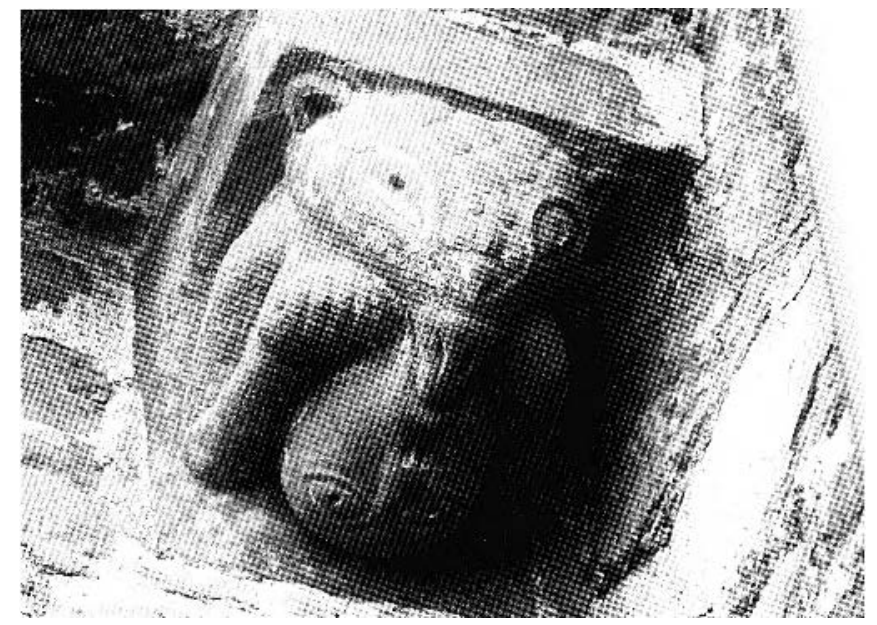

Figure 5. Corbel no. 35 (beakhead creature devouring a human head). St. Mary and St. David, Kilpeck. Oxfordshire (Photo: Malcolm Thurlby).

east end of Barfreston Church. These heads were easily visible, being little more than two meters above ground level (fig. 3). The intensity of the imagery may have complemented the moral judgments found in sermons or could have represented humorous distractions. The head with its tongue protruding from an open mouth is precisely the type of image that Bernard complained about. Its position on the east end of Barfreston, nevertheless, must have been within the limits of the ('hurch's tolerance because the motif, and others like it, has remained intact since the twelfth century. If St. Bernard's bias against "ridiculous monstrosity" was universally accepted, the church ought to have sanctioned the destruction of the offensive motifs. The preservation of these corbels signals two possibilities: the Church tolerated the offensive motifs because they held some kind of popular cultural appeal, or the imagery also scrved a moral function. If the latter is true, then the clergy must have felt that these images werc connected to the maintenancc of social order, particularly in reference to condemning sexual sin.

\section{Moral Messages in Stone}

A variety of beasts with mouths agape and tongues protruding is abundant on some English corbel tables. At Barfreston, corbels nos. 15, 17, and 20 of the south nave, no. 5 of the south chancel, as wcll as nos. 3 and 6 of the east end are of this type, usually referred to as tongue-protruders (fig. 4). 'Ihe clergy may have instructed artists to add tongue-protruders to programs of sculpture because the imagery was a rude gesture symbolizing immoral behaviour. These images were likely visual reminders of sermons against sin. However, moral messages were represented in many more complex and multifarious ways. At Kilpeck, there 


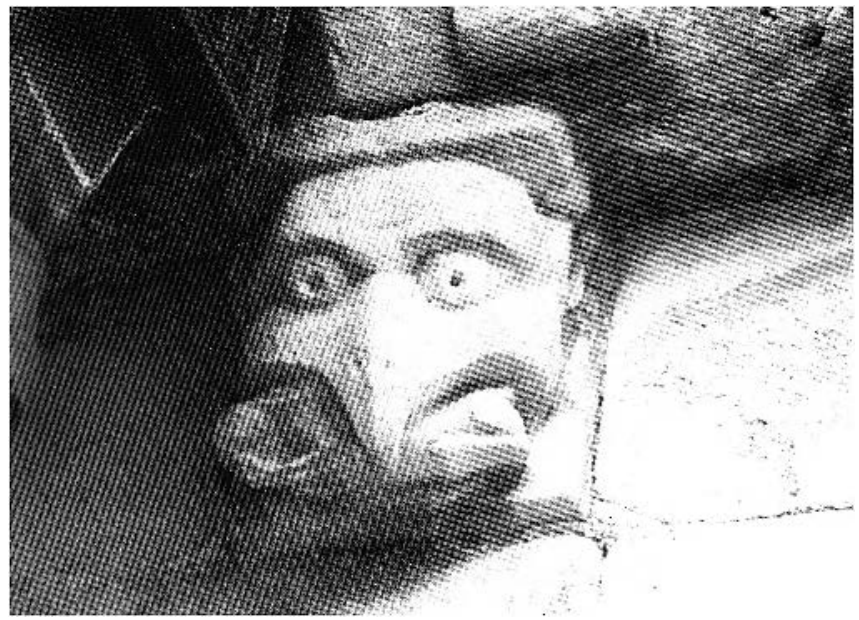

Figure 6. Corbel no. I of the south chancel (beakhead dcvourıng rabbit), St. Nicholas, Barfreston, Kent (Photo: Barry Magrill).

are images of human heads devoured in the mouths of bird-like creatures called beakheads, and these occur on corbcls numbered $35,50,69$, and 85 . The Church took advantagc of the primordial fear of being devoured by animals in its claims that sinners would be eaten for evil deeds for which they did not repent. A clear example occurs at St. Helen's, Kilnwick Percy (Yorkshire), where an animal head depicted on a corbel on the south wall has two human heads extruding from either side of its mouth. Another occurs on corbel no. 35 on the north side of the apsc at Kilpcck (fig. 5). The motif is repeated ac Barfreston, on a corbel located at the junction of the nave and chancel, where a beakhead creature devours a rabbit (fig. 6). The rabbit represents the frailty of the human condicion. Other motifs have been identified as having clear sexual characteristics relating to sin and punishment, such as dancing figures exhibiting sexual poses that occur on the Prior's Door at Ely Cachedral and a female exhibitionist figurc (now mutilated) holding a fish, found on a central lunctte at Rochester Cathedral (in Kent, not far from Barfreston).

The depiction of mouth-pullers is also ubiquitous in English Romanesque sculpture. A mouth-puller and tongue-protruder appear at Studland on the southwest and northwest corbels of the nave and on south nave corbel no. 8 (fig. 7). Other examples of mouth-pullers can be found on a corbel preserved in the Victoria and Albert Museum,26 and on corbels on the southeast angle of the chancel at St. James, Cradley (Herefordshire), on the eastern angles of the chancel at St. Michael's, Withington (Gloucester), on the north wall of the west tower at St. Nicholas, Twywell (Northampton), on the south nave wall at St. Mary's, Kirkburn, on the south transept chapel at Romsey Abbey, and on the west clerestory of the south transept of Winchester Cathedral, where it is in the guise of the devil.

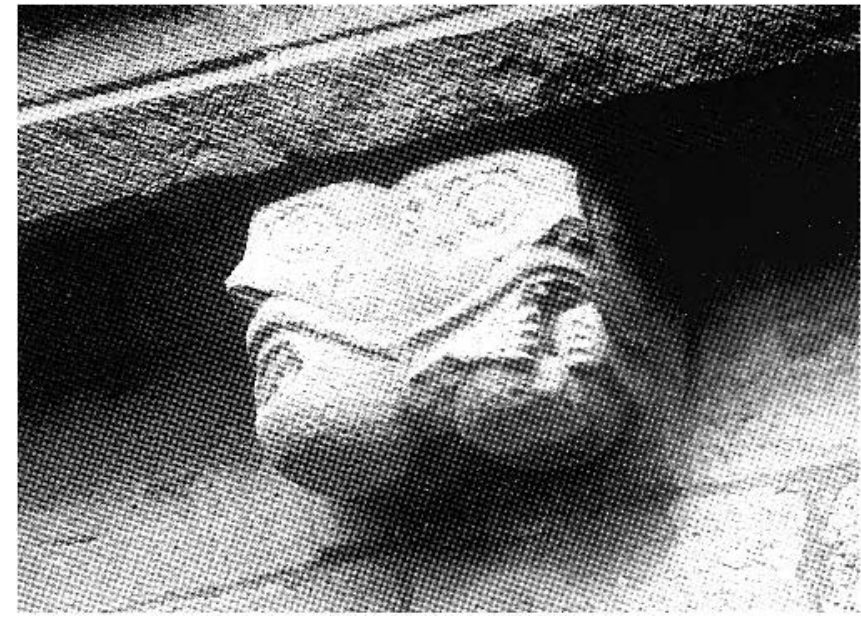

Figure 7. Corbel no. 8 of the south nave (tongue-protruder). St. Nicholas, Studland (Photo: Malcolm Thurlby).

The Church prohibited numerous secular activities including musical performances outside of the patronage of the Church. Musicians appear frequently on corbels, especially on parts of French churches, including the main apse at the church of Martha-Marestay (Charente-Maritime), where a viol player is adjacent to a dancing, cowering figure with outstretched arms. On the other side of the Martha-Marcstay viol player is a monster devouring two souls, illustrating a warning about the danger of seduction by music (fig. 8). Martha-Marestay cxhibits a good, yet rare, example of sequential narrative in corbel carving, an arrangement that did not typically occur in English Romanesque churches. An exception is in a similar cnsemble at Kilpeck, where a viol player is juxtaposed to a dancing couple (fig. 9). The male figure on the left gropes the female who, in turn, grasps his elbow to restrain further movement. The angle of the female's head also suggests resistance to a kiss. As if to accompany this warning about the dangers of lusty advances stimulated by intoxicating music, the figure on an adjacent corbel appears to recoil, with legs crossed, at the impending violation.

A variecy of other sins were represented among carved corbels. For instance, warnings against over-indulgence in wine, beer, or cider are depicted on corbels on the north wall at Studland and on the north nave wall of St. Mary's, Kirkburn. 27 These shorthand references to the collapse of social controls are made all the more explicit in some corbels in Saintonge, as at the church at Givrezac (Charente-Maritime), where a barrel is carried by a priapic devil.28 The depiction of revelry is particularly interesting in light of the Church's desire to control secular enjoyment, especially when the location of corbel imagery on the outside of the church fabric, facing secular space, is taken into account. In this sense, church iconography reaches beyond the sacred confines of 


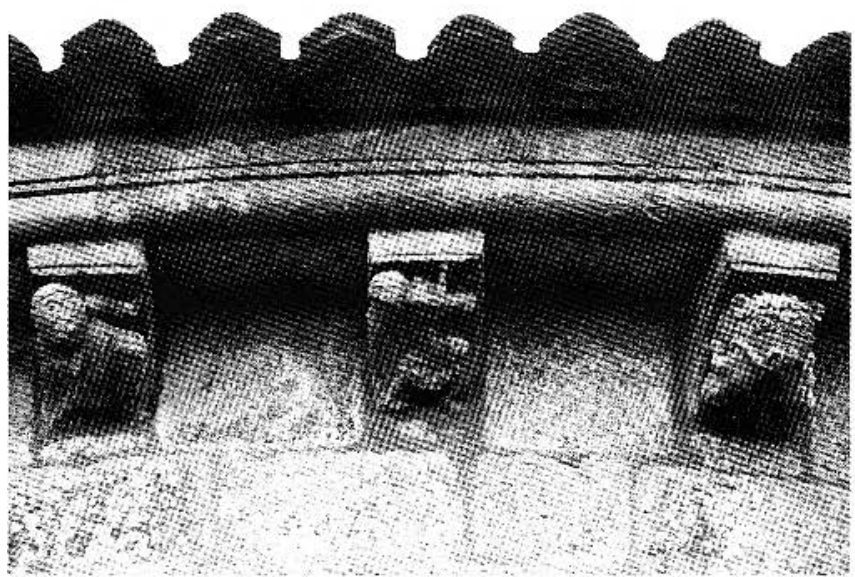

Figure 8. Corbel table at Martha-Marestay, Charente-Maritime (viol player dancing between cowering human and a monster devouring two humans) (Photo: Ma colm Thurlby).

the church building and into the mundane but sinful world. The question that is difficult to answer with certainty is whcther people laughed or trembled at the depictions of sinful bchaviour. It is possible that ordinary folk were both afraid and entertained by the predicament they found themselves in, full of sin but without the resources to purchase indulgences to allcviate it.

\section{Sexual Sin on Corbel Tables}

Imagery of a sexual nature often abounds on the corbel table. It is difficult to determine with certainty if images of mcgaphallic figures or copulating couples, for instance, were sanctioned as deterrents from sexual behaviours. Clearly the Church wanted to control social practice, especially in connection with sexuality. ${ }^{29}$ The problem was, of course, that it had to depict the very activity it wanted to abolish, and thus inadvertently risked encouraging the so-called deviant behaviour. Perhaps the obverse was true: the Church understood that peoplc routinely partook of sexual sin and therefore no risk of encouragement existed. The produccrs of the corbel imagery must have been accustomed to the idea that imagery had a multiplicity of interpretations. A megaphallus figure occurs inside the nave at the Holy Cross Church, Avening (Gloucestershire) (fig. 10), where it was reinstalled from its original setting outside of the building. Another megaphallus is located on the north side of the crossing tower at St. Kyneburgh at Castor (Northampton), and may have been humorous to labourers but also represented scrious business to the nobility educated in Church doctrine. At the same time, literate and illiterate folk alike would have been continuously reminded of the sexual misconduct represented by the phallic symbolism.

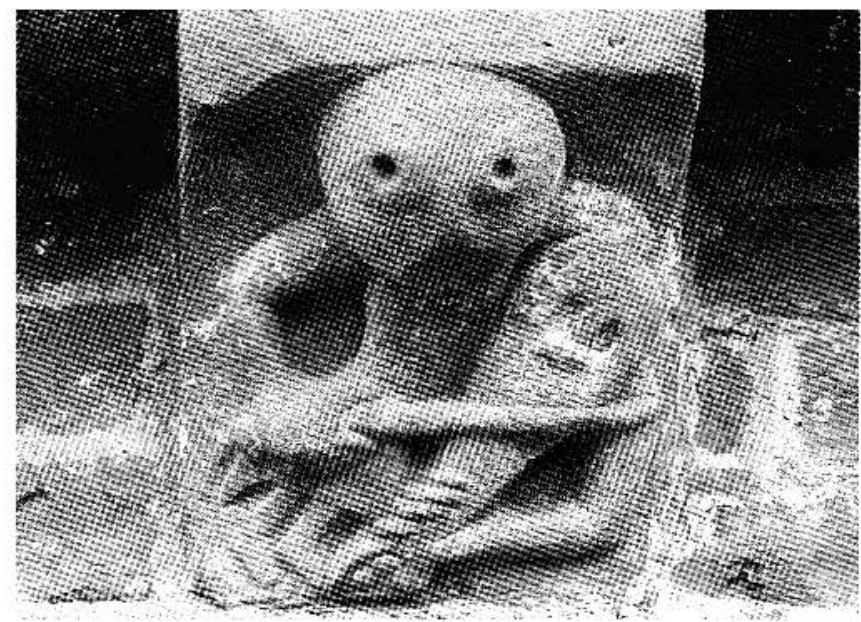

Figure 9. Corbel no. 43 (viol player). St. Mary and St. David, Kilpeck Oxfordshire (Photo: Malcolm Thurlby)

A clear example of moral messages associated with carved corbels in England is found in the representation of a copulating couple on a corbel at Studland, just to the right of the south porch. The exaggerated proportions of the figures portray a violent sexual encounter, an overt, lusty display, which is matched by a priapic figure (damaged) on corbel no. 23. Folk could not have missed seeing the promincnt image of lust upon entering the church, and the distortion of the figures into grotesques likely was intended to allay their passions. At Kilpeck a clear display of scxual impropriety occurs on the westernmost corbel of the south side of the apse. Here a female exhibitionist, with a grossly cnlarged head, pulls open her vulva with her left hand. She is closely comparable with the famous female exhibitionist on a corbel on the south side of the apse of Kilpeck church, where other corbels warn of the dangers of sexual promiscuity. 30

An analogous message is evident in one of the corbels on the north nave wall at All Saints, Lullington (Somerset), on which two malc apes, exhibiting large testicles and anuses, strugglc in a tight embrace (fig. 11). In this casc, the motif points out that sodomy and homosexuality were sins of equal weight. One must bear in mind when dealing with sexual imagery carved onto the fabric of churches that it represented a way of merging the moral and the deviant, the otherworldly and the mundane, the institutional and the popular.

\section{Bestiaries and Carved Corbels}

Some of the figurative imagery carved on corbels appears to have becn derived from literary sources, especially bestiaries. These bound volumes of mystical zoology typically included vi- 


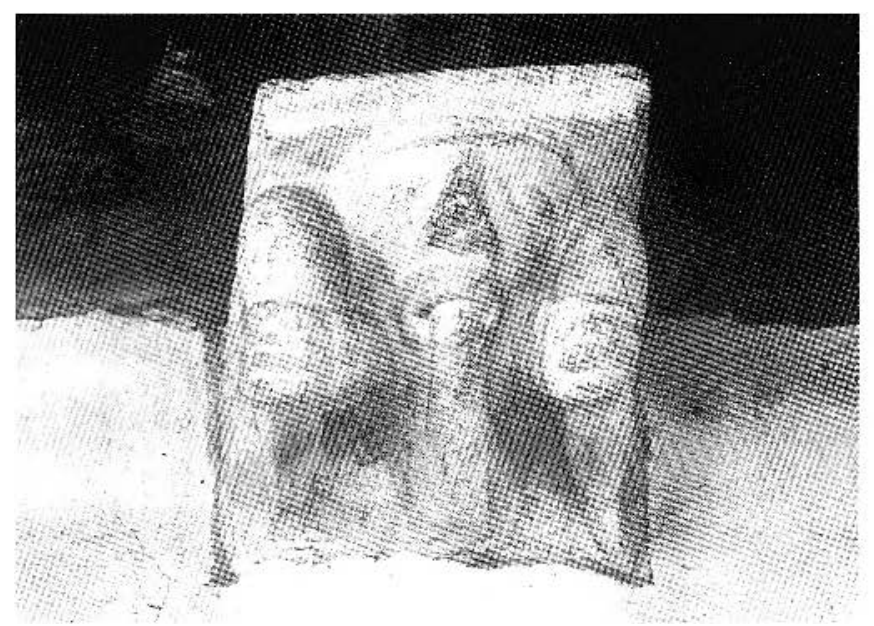

Figure 10. Megaphallus corbel at Holy Cross. Avcning, Glouccstershire (Photo: Malcolm Thurlby).

sual and textual components describing the natural and moral characteristics of real and imaginary animals. For example, the bestiaries associated the femalc bird-human hybrid, called a siren, with immoral temptation. The connection between carved sculpture on medieval churches and the bestiaries has been difficult to determine except in a few well-known cases. The church of St. Mary, Alne, has figurative motifs carved in the voussoir stones with identifying inscriptions related to the $\mathrm{Ox}$ ford Bodleian MS Laud bestiary. ${ }^{31}$ The interpretation of most carved sculpture, however, remains speculative and open to ncw interpretation. The use of bestiaries in the education of illiterate acolytes of the medieval Church ${ }^{32}$ suggests the possibility that carved images of bestiary figures were instructive in purpose. I subscribe to the notion forwarded by Ron Baxter, who argues that the bestiaries were systematically organized around ideological themes. 33 If this is correct, there is no reason not to believe that carved corbels making references to hybrids found in bestiaries were also organized systematically.

A fundamental question about the transmission of bestiary images, and their accompanying moral subjects, to carved ornament concerns the availability of bestiaries to the carvers. As precious and expensive items, bestiaries wcre the property of monastic libraries that did not allow their removal from the premises. ${ }^{34}$ In reality, illiterate carvers likely learned about bestiary imagery and its moral messages through word of mouth. Convincing visual connections between the bestiaries and carving exist. For instance, an ibex at Kilpeck is carved upside-down in precisely the way it was described in the bestiary, with its two horns absorbing the full weight of its body when falling and saving the beast from harm. Reading from

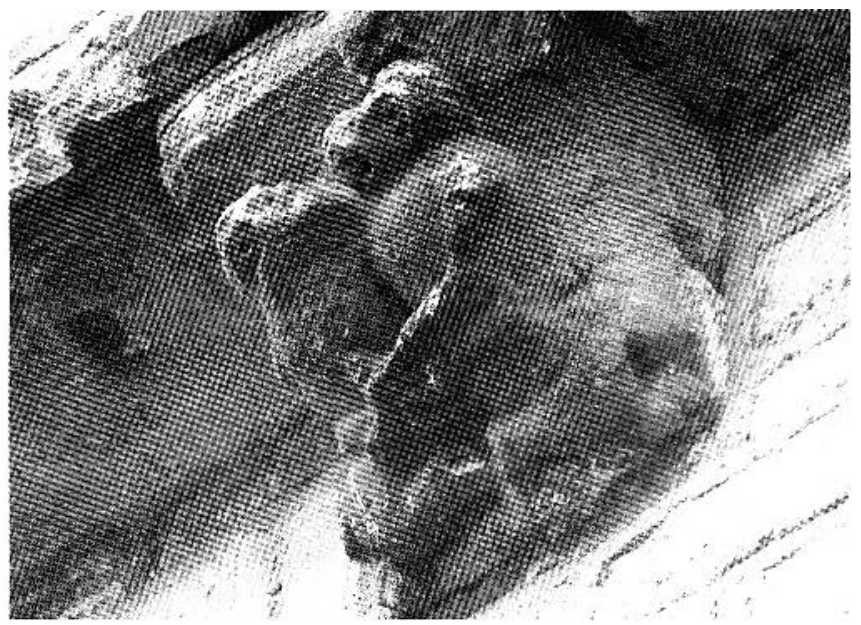

Figurc II Simian imagery on a corbel at All Saints, Lullington. Somerset (Photo: Malcolm Thurlby).

Scripture was claimed to have had similar effects, according to the Church. ${ }^{35}$

Sexual sin appears to have been a typical interpretation of the scxualized imagery found among corbels depicting forms of animals and hybrid creatures. However, the theme of salvation is also present. Turning to the bestiaries as a source of interpretation, representations of the dog, the hare, the stag, and probably the ram offered the path of righteousness to be followed by the Christian in search of salvation. Dogs, such as the one depicted on a corbel at Kilpeck, were described in the bestiaries as having "more understanding than any other beast. They also know their name and love their master." 36 Thus, the clcrgy could have believed that anthropomorphism would influence the ordinary folk who experienced reality chiefly through the natural world. Also at Kilpeck is a corbel carved with an image of a stag represented, in the grammar of the bestiarics, as the enemy of scrpents. The stag was associated with revitalization, loyalty, cleanliness, youthfulness, good deeds, and humility. ${ }^{37}$ Culturally and cconomically the hunt and hunting had separate but interconnected connotations for elite and ordinary folk.

A few other animals were associated in bestiaries with evil and temptation. Kilpeck has a corbel, no. 27, that depicts a pig, an animal recorded in bestiaries as "a filthy beast [that] sucks up filth, wallows in mud, and smears itself with slime." 38 The female pig was associated with "sinners, the unclean and herctics" intent upon carnal things. ${ }^{39}$ The pig shown at Kilpeck was a suitable accompaniment for the he-goat on corbel no. 87, an animal that the bestiaries documented as "a stubborn, lascivious animal who is always eager to mate." 40 


\section{Deformity and Hybridity}

Animals were customarily depicted as deformed creatures when they appeared on the corbel table. A deformed ram's head appears on corbel no. 16 at Kilpeck and several varieties of animal occur at Barfreston. It was common practice to distort the facial features of human characters depicted on corbels, although the extreme range of distortion produced heads almost entirely divorced from humanity. The deformities depicted among the human and animal motifs under the string course on the east end at Barfreston suggest terrifying and wondrous supernatural forces. Thus, the distortion of human and animal figures was associated with impurity, disloyalty, and disharmony.

Hybridity was a different issue because it was constituted through the interface of two uncorrupted states. In essence, hybridity described the interface of sacred and secular social patterns in the production of a third space capable of expressing hyperbole as no other space could. For good reason the twisted features of deformed heads were excluded from the high altar, the central space reserved for sanitized depictions of Christ. Humanoid lion heads at Barfreston, for instance, indicate that the producers and audiences of corbels recognized that the unclean could only be tolerated on the edges of the fabric of the church. For this reason deformed heads appear on the exterior of the church located high up on the corbel table or on the exterior side of entrances. Barfreston has a humanoid lion head carved on the exterior capital of the north doorway.

As a hybrid space, the corbel table reflected aspects of both official and ordinary life. Ordinary folk must have been able to recognize instances of the wondrous and the mundane on the corbel table, including their manner of interface. The intersection of sacred and secular space points out the coextensive natures of popular and official culture. These viewpoints were so closely related that pcople from across the social spectrum likely had difficulty comprehending the distinctions between religious and secular life. What they saw instead was variety. Mundane animal motifs including dogs, pigs, horses, and cattle were eclectically juxtaposed to exotic felines and forest animals associated with the hunt and elite society.

\section{Conclusion}

Corbel carving has received little attention because scholars looked for logical and unified sculptural programs when none were to be found. The intent of sculptural programs that appear in the more remote areas of the church fabric cannot always be clearly defined. Subsequently, carved corbels were categorized within a corpus of decorative, rather than edifying, medieval sculpture except in cases where sexual imagery appears to be clearly linked to moral messages. There remains some ambigu- ity about the level of sanction that sexual imagery received from the Church. Two opposing positions have been used to describe the purpose of sexual and otherworldly imagery on corbels: humour and fear. Rather than adhere to a polemic argument, this paper has indicated that the variety of carved imagery found on corbels appears to suggest that audiences of vastly different social spheres saw things in the depictions that accommodated their own worldviews. Only on the corbel table could one expect to find terrifying and deformed creatures, the remnants of supernaturally changed animals. Only on the corbel table could one expect to find humans and animals distorted to the point of hybridity, the result of mixing separate categorics of beings. Only on the corbel table could one expect to find representations of sexual misconduct represented as the actual behaviours the Church wanted to abolish. Only through the corbel table would one expect to experience fear and humour at the same moment, when multiple gazes of different viewers converge in the same space.

\section{Acknowledgements}

Many people contributed to the research and publication of this paper. My gratitude to Malcolm Thurlby, a colleague and friend, for guiding me through Romanesque sculpture and loaning key images for publication. Carol Knicely provided a source of wonderful support and advice for the theoretical components of this paper. I would also like to acknowledge the editorial support of Brian Foss, Barbara Winters, and the anonymous reader whose remarks were greatly appreciarcd during the final drafts.

\section{Notes}

1 A fuller description of Kilpeck can be found in Malcolm Thurlby, The Herefordshire School of Romanesque Sculpture (Herefordshire, 1999), 3870.

2 Interest in the archaeological remains of the Gothic period was sparked by archirect Augustus Welby Northmore Pugin's books Contrasts (1836) and True Principles (1841). Earlier literature, including Thomas Rickman's An Attempt to Discriminate the Styles of Architecture in England (1817), which attributes precise names to architectural styles, influenced the appropriation of the medieval past for political and cultural purposes in the nineteenth century. Sec also "A Few Hints on the Practical Study of Ecclesiastical Antiques," first published as a pamphlet series by the Cambridge Camden Society in 1839; the 4th edition is reprinted in Christopher Wcbster, ed., "Temples... Worthy of His Presence": the Early Publications of the Cambridge Camden Society (Reading, 2003), 63-126.

3 Joseph Gwilt, An Encyclopaedia of Architecture, Historical, Theoretical, and Practical (London, 1903), 1254. 
4 A typical formal approach is takcn by A.H. Collins in "The Sculptured Ornament of the South 1)oorway of Barfreston Church," Archacologia Cantiana XI.V (1933): 3. He argucs that "the sculptor's object in carving these scencs was on the whole to ornament the fabric rather than to cdify the congregation," and urges observers not to look for a consecutive order to the sculptural arrangement. Collins's formalist approach to art history was the typical of the time, cven though social art history had already been an accepted methodology.

5 Ihe cminent historian Emilc Malc's (rothic Image: Religious Art in France (ca. 1910; New York, repr. 1958) and Religious Art in France: A Study of Medieval Iconography and its Sources (Princeton, NJ, repr. 1984) exemplify art-historical interests parallcling nationalist agendas.

6 Ceorge 7arnecki, in English Romanesque Sculpture 1066-1140) (london, 1951), amplifies the decorative nature of marginal motifs carved in England. Sce also Larnecki, Later Linglish Romanesque Sculpture 1140-1210)(London, 1953).

7 Anthony Weir and James Jcrman, Images of Lust: Sexual Carvings on Medieval Churches (London, 1986), 11-22. A useful website containing a large collection of Britain's Sheilas is hetp://www. sheelanagig.org/.

8 Aron (iurcvich, Medicval Propular (ulture: Problems of Belice and Perception (Cambridge, LK, 1988). The book remains a significant reading of the medieval social sphere.

9) Michael Camille, Image on the Edge (London, 1992), 75.

10) Sec Charles Keyser, A list of Norman tympana and lintels, with figure or symbolic sculpture still or till recently existing in the churches of Great Britain (I.ondon, 1904).

11 See T:H. Worsfold, A Ciuide to Barficystone Church and its World Famous Carvings (n.p., 1949).

12 Sec Ron Baxter, Bestiaries and Iheir Users in the Middle Ages (I.ondon, 1998), 62. Baxter argues that later versions of essentially the same book, which became known as the bestiary, had additional passages based upon Isidore of Seville's book of animal classification, called the Etymologiae; sec Baxtcr, 83-85.

13 A.H. Collins, "The Sculptural (Ornament of the South 1)oorway of Barfreston (Church,"Archaeologia Cantiana XI.V (1933): 3.

14 The inconsistency in the south doorway was amplified by the fact that its masons mixed up a few stones during installation, consequently inverting one of the motifs. Worsfold noted it in 1949, as did others, though my own observations indicate that any orher combinations of stones would still yield the inverted motif of the two figurcs wrestling. One could conclude that the wresting figures werc delibcratcly carved upside down before installation.

15 Chapter one in Baxter, Bestiaries and Their Users, contains an historiographical analysis of bestiaries that illustrates the limitations of symbolic analysis that originated with J.R. Allen and George Druce. Baxter prefers to centre attention on the mobility of meanings with respect to the consumption of bestiarics, noting that
M.R. James (1928) had alrcady tackled the construction of the bestiary as a discursive unity. 'This discussion has largely gone unnoticed with regard to carved figurative corbels.

16 William of Malmesbury makes notc of the new style of architecture in Lingland, meaning Gothic imported from Normandy, in his massive volumes Gesta Regum and Gesta Pontificum, which were allegedly completed by 1125 .

17 Malcolm Ihurlby, Herefordshire School, 1-8.

18 Malcolm Thurlby and Karen I.undgren, "The Romancsque Church of St. Nicholas, Studland (Dorset)," Proceedings of the Dorset Archacological and Natural History Society 121 (I)orset, 1999): $1-16$.

19) Thurlby, "The Romancsque Church of St. Nicholas, Studland (I)orset)," Proceedings: 16.

20) 'Ihurlby, Herefordshire School, 11.

21 "Ralph of Courbépine held 1 yoke in Barfreston for the Bishop of Bayeux, there a poor woman paid $31 / 2 \mathrm{~d}$ the valuc of which was always 10s," in John Morris, cd., Domesday Book (Chichester, 1983), 5,132 .

22 Charles Clarke, "Barfreston Church," Architectural Antiquities of (ireat Britain, ed. John Britton (L.ondon, 1835), 21.

2.3 Explained in detail in F.H. Worsfold, A Guide to Barfreystone Church and Its World Famous Carvings, 9th ed. (n.d.), 3.

24 Nikolaus Pevsner, The Buildings of England, Herefordshire (Harmondsworth, 1963), 202.

25 The entire letter is found in appendix 10 in Wolfgang Braunfels, Monasteries of Western Furope: the Architecture of the Orders (Princeton, 1972), 241-42.

26. Paul Williamson, A Catalogue of Romanesque Sculpture (L.ondon, 1983), cat. 40.

27 Rene Crozet, l'Art Roman en Saintonge (Paris, 1971).

28 Weir and Jerman, Images of I.ust, illustrated in fig. 37b.

2) Wcir and Jcrman, Images of Lust, 35.

30) Thurlby, Herefordshire School, 51-67.

31 Baxter, Bestiaries and their Users, 247.

32 Franc Bauml, "Varieties and Consequences of Medieval Litcracy and Illiteracy," Speculum 55 (1980): 237-65.

33 Baxcer, Bestiaries and their Users, 2\%.

34 Baxter, Bestiaries and their Users, 195. Baxtcr points out that in Fingland a bestiary in lay owncrship was recorded only once; see p. 160 .

35 Richard H. Barber, Bestiary: Being an English Version of the Bodleian Library, Oxford MS Bodley 764 (London, 1992), 44. See also Thurlby, Herefordshire School, 58, showing an image of the corbel inverted.

36) Barber, Bestiary, 72.

37) Barber, Bestiary, 51-52.

38 Barber, Bestiary, 86.

39) Barber, Bestiary.

40) Barbcr, Bestiary, 83. 